\title{
Facial paralysis caused by dislocated incus following head trauma in a pediatric patient: $A$ case report
}

\author{
Pediyatrik bir hastada kafa travması sonrasında inkus dislokasyonuna bă̆lı fasiyal paraliz: \\ Olgu sunumu
}

\author{
Nurullah Seyhun (1), Senem Kurt Dizdar (1), Alican Çoktur (1), Suat Turgut (1) \\ Department of Otolaryngology, Şişli Hamidiye Etfal Training and Research Hospital, İstanbul, Turkey
}

\begin{abstract}
Temporal bone fractures following head trauma may be associated with facial paralysis which causes significant morbidity. Ossicular chain disruptions can also occur, leading to hearing loss. A 12-year-old patient was admitted to our clinic with facial paralysis caused solely by the dislocated incus following a head trauma. Longitudinal temporal bone fracture was also present. Surgical decompression with ossiculoplasty showed significant improvement in both hearing loss and facial paralysis. In such cases, surgical approach may be required. Electroneuronography and electromyography are helpful in deciding the surgical intervention. If there is an ossicular chain disruption, ossiculoplasty should be also performed concurrently. Keywords: Facial paralysis, head trauma, incus dislocation, temporal bone fracture.
\end{abstract}

Facial paralysis following a head trauma is mainly caused by temporal bone fractures. Compression of the facial nerve by the bony fragments, intraneural edema or both, accounts for the majority of facial paralysis following temporal bone fractures. ${ }^{[1]}$

Temporal bone fractures are classified into three types as longitudinal, transverse, and mixed type, according to the relation of the fracture line to the long axis of petrous bone. ${ }^{[2]}$ Alternatively, temporal bone fractures can be classified as otic capsule
$\ddot{O Z Z}$

Kafa travması sonrasında temporal kemik kırıkları, önemli morbiditeye yol açarak, fasiyal paraliz ile ilişkili olabilir. İşitme kaybına neden olan ossiküler zincir hasarları da görülebilir. On iki yaşında olgu kafa travması sonrasında yalnızca inkus dislokasyonuna bağlı fasiyal paraliz ile kliniğimize başvurdu. Uzunlamasına temporal kemik kırığı da mevcuttu. Ossikülopati ile cerrahi dekompresyon hem işitme kaybında hem de fasiyal paralizde anlamlı iyileşme sağladı. Bu tür olgularda cerrahi yaklaşım da gerekebilir. Elektronörografi ve elektromiyografi, cerrahi girişim kararının verilmesine yardımcıdır. Ossiküler zincir hasarı mevcut ise, eş zamanlı ossiküloplasti de yapılmalıdır.

Anahtar sözcükler: Fasiyal paraliz, kafa travması, inkus dislokasyonu, temporal kemik kırığı.

sparing or otic capsule disrupting fractures. ${ }^{[2]}$ Facial paralysis is more frequently seen in otic capsule disrupting fractures and presents almost always with a sensorineural hearing loss (SNHL). Otic capsule sparing fractures are more frequent and facial paralysis is less common. ${ }^{[2]}$ Conductive hearing loss (CHL) is the main finding suggesting an ossicular chain lesion, although traumatic hemotympanum may be also the reason which may recover within a few days to weeks. ${ }^{[3]}$

Received: February 02, 2019 Accepted: May 10, 2019 Published online: September 03, 2019

Correspondence: Nurullah Seyhun, MD. Şişli Hamidiye Etfal Eğitim ve Araştırma Hastanesi Kalp ve Damar Cerrahisi Kliniği, 34371 Şişli, İstanbul, Turkey. e-mail: seyhun90@hotmail.com 
Herein, we present a pediatric case of facial paralysis caused solely by impingement of the dislocated incus and temporal bone fracture following a head trauma.

\section{CASE REPORT}

A 12-year-old female presented to our clinic in July 2017 with left-sided facial paralysis and hearing loss (HL) on the same side following a fall from height 10 days before her admission. After the incident, she was admitted to an external hospital, and cranial computed tomography (CT) showed no intracranial abnormalities, except for a left-sided longitudinal temporal fracture. Grade 3 facial paralysis was present after the incident and prednisolone treatment was initiated on the basis of weight-adjusted dosing. Conservative management was planned and the patient was discharged the next day.

However, as the facial paralysis progressed, the patient was admitted to our clinic. At the time of admission, physical examination revealed Grade 5 facial paralysis with intact tympanic membranes without hemotympanum. Grading of facial paralysis was established according to the House-Brackmann classification. ${ }^{[4]}$ Pure tone audiometry showed that airconduction threshold was $67 \mathrm{~dB}$ and bone-conduction threshold was $35 \mathrm{~dB}$ with an air-bone gap of $32 \mathrm{~dB}$, indicating a mixed type of HL. The CT scan of the temporal bone showed a left-sided longitudinal temporal bone fracture (Figure 1). Incus was dislocated and was impinging on the tympanic segment of the facial nerve (Figure 2). Electroneurography (ENoG) showed 90\% of facial nerve degeneration on Day 11 of the incident.

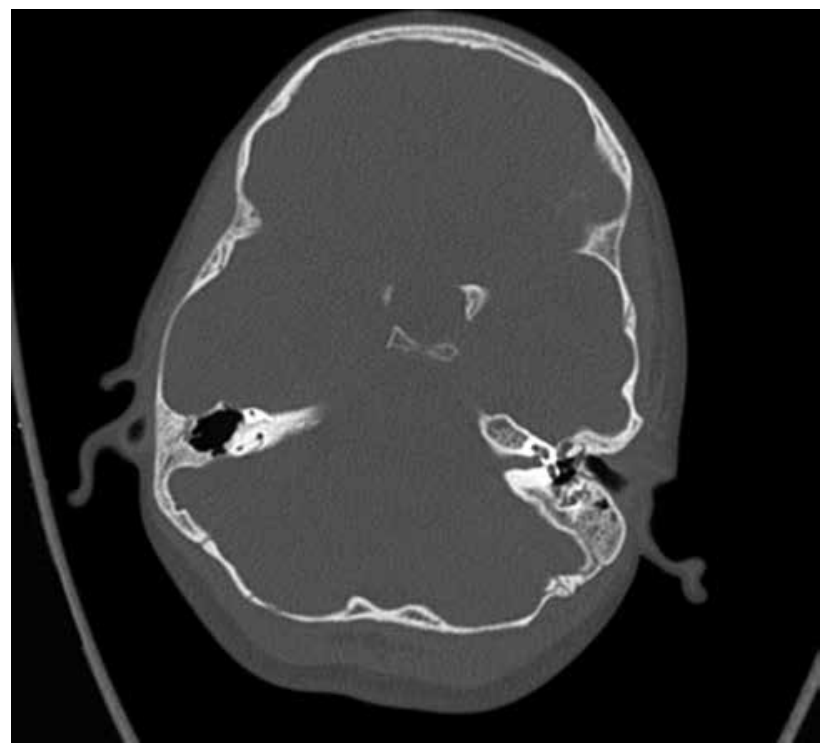

Figure 1. A left-sided longitudinal temporal bone fracture on high-resolution computed tomography.
Facial nerve decompression and surgical exploration was planned under general anesthesia. Mastoidectomy was performed and incus was not seen in the fossa incudis. Posterior tympanotomy was performed, and stapes and pyramidal eminence were seen. The stapes was intact, but the incudostapedial joint was dislocated. The incus was impinging on the facial nerve at the level of cochleariform process, and the incus was removed. Bony canal of the facial nerve was damaged at this level and was uncapped. The nerve sheath was slit and the facial nerve was decompressed. Ossiculoplasty with incus interpositioning was performed. The bone cement was used at the junctions and the ossicular chain was intact. Prednisolone treatment adjusted to the weight was continued postoperatively, and the patient was discharged two days after the operation. At one month of follow-up, facial paralysis regressed to Grade 3. At three months, facial paralysis completely resolved. Pure tone audiometry showed an air conduction threshold of $24 \mathrm{~dB}$ and a bone conduction threshold of $12 \mathrm{~dB}$, indicating a great improvement, compared to preoperative results. A written informed consent was obtained from each parent.

\section{DISCUSSION}

Temporal bone fractures mostly occur following a head trauma and can be associated with facial paralysis, leading to a significant morbidity. Otic capsule sparing fractures are more common and facial paralysis has been reported in 6 to 14\% of patients, whereas otic capsule disrupting fractures account for facial paralysis in 30 to $50 \%$ of patients. ${ }^{[5]}$ In addition, CHL, SNHL, and mixed type of HL may be observed. Hemotympanum

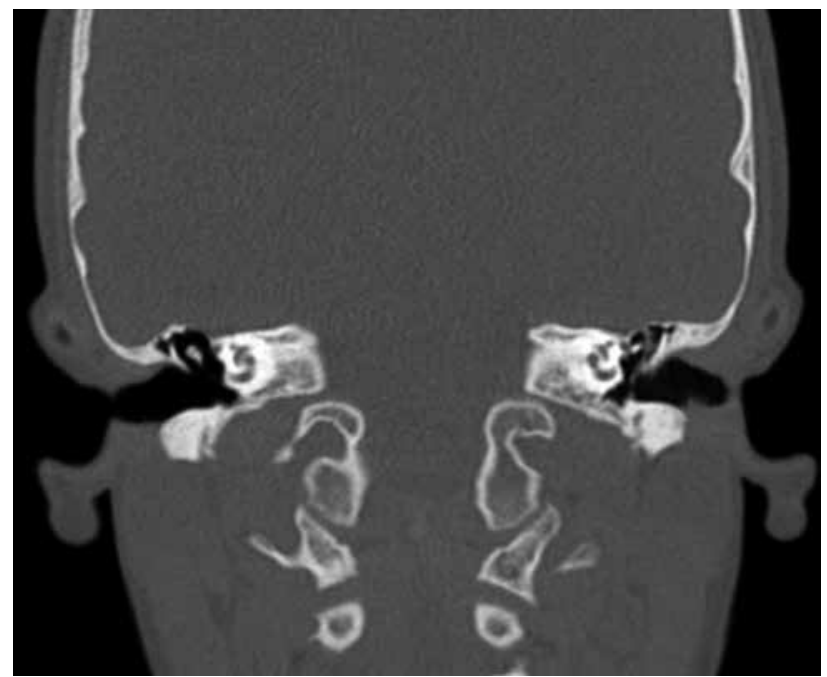

Figure 2. A dislocated incus impinging on tympanic segment of facial nerve. 
or traumatic tympanic membrane perforations are the most common causes of CHL, although ossicular chain disruptions can be also seen frequently. Dislocation is the most common type of ossicular chain injury, and incudostapedial joint dislocation is the most frequent dislocation type ${ }^{[6]}$ Hemotympanum resolves within a few days to weeks following trauma; however, exploration of the middle ear and ossicular chain is recommended, if 30-dB CHL persists for more than two months. ${ }^{[2]}$

Previous studies have demonstrated that temporal bones of children are more flexible than adults, as there is less mineralization in children, protecting the otic capsule from injuries. Therefore, the incidence of SNHL and facial paralysis associated with temporal bone fractures are lower than adult population. ${ }^{[7]}$ However, there is still controversy regarding the indications of surgical management of facial paralysis in patients with temporal bone fractures. Fisch ${ }^{[8]}$ reported that facial nerve decompression was necessary in patients with $90 \%$ of nerve degeneration in $\mathrm{ENoG}$ in early stage (within six days of trauma). However, it is not always possible to evaluate patients with temporal bone fractures in early stage, as patients may suffer from multiple traumas at the same time. Liu et al. ${ }^{[9]}$ also recommended surgical decompression within one month after the incident, as motor neuron cell bodies typically recover 21 days after the damage and they suggested that the curative effect would be most beneficial in this period. In another study by Ulug and Arif Ulubil ${ }^{[10]}$ six patients who were operated at two and three months of the incident achieved improved outcomes, compared to five patients who were operated within the first month of the incident, which is clearly not consistent with the previous reports. Similarly, in a recent study by Yadav et al., ${ }^{[1]}$ conservative approach, even for complete facial paralysis patients, was strictly recommended. The authors observed that, even after three months, complete facial paralysis might recover and satisfactory results could be achieved. Even in case of poor ENoG results, they suggested waiting up to three months before any surgical intervention. However, in our report, the patient definitely needed a surgery for traumatic dislocation of the incus to improve hearing. Thus, considering the gradually worsening course of facial paralysis and poor ENoG results, decompression of the facial nerve in a single session was a favorable choice.

To date, several surgical approaches have been used for decompression, depending on the site of injury. Middle cranial fossa approach is mainly used for injuries located before the geniculate ganglion. ${ }^{[9]}$ Transmastoid approach is another option, if the injury involves the mastoid or tympanic segment. ${ }^{[9]}$
Electroneuronography is a very useful method to evaluate the need for a surgical exploration in the early period. Over $90 \%$ of degeneration in the nerve fibers suggests that surgical decompression should be carried out to improve the outcome. However, the majority of patients with trauma are referred to an otologist after a couple of weeks following the incident. In such case, EMG can be performed for a possible surgical approach which yields reliable results in the late period. ${ }^{[12]}$

In conclusion, it is of utmost importance to evaluate the facial nerve functions and hearing in patients with temporal bone fractures. Although very rare, dislocated ossicles impinging on the facial nerve may be the reason for facial paralysis. If the paralysis is progressively worsening or ENoG shows significant nerve degeneration, surgical decompression is recommended. If there is also ossicular chain disruption, ossiculoplasty should be performed concurrently.

\section{Declaration of conflicting interests}

The authors declared no conflicts of interest with respect to the authorship and/or publication of this article.

\section{Funding}

The authors received no financial support for the research and/or authorship of this article.

\section{REFERENCES}

1. Ashram YA, Badr-El-Dine MM. Surgery for traumatic facial nerve paralysis: does intraoperative monitoring have a role? Eur Arch Otorhinolaryngol 2014;271:2365-74.

2. Diaz RC, Cervenka B, Brodie HA. Treatment of Temporal Bone Fractures. J Neurol Surg B Skull Base 2016;77:419-29.

3. Grant JR, Arganbright J, Friedland DR. Outcomes for conservative management of traumatic conductive hearing loss. Otol Neurotol 2008;29:344-9.

4. House JW, Brackmann DE. Facial nerve grading system. Otolaryngol Head Neck Surg 1985;93:146-7.

5. Brodie HA. Management of temporal bone trauma. In: Flint PW, Haughey BH, Lund VJ, Niparko JK, Richardson MA, Robbins KT, et al. editors. Cummings Otolaryngology Head \& Neck Surgery. 5th ed. Philadelphia: Mosby; 2010. p. 2036-47.

6. Yetiser S, Hidir Y, Birkent H, Satar B, Durmaz A. Traumatic ossicular dislocations: etiology and management. Am J Otolaryngol 2008;29:31-6.

7. Waissbluth S, Ywakim R, Al Qassabi B, Torabi B, Carpineta L, Manoukian J, et al. Pediatric temporal bone fractures: A case series. Int J Pediatr Otorhinolaryngol 2016;84:106-9.

8. Fisch U. Facial paralysis in fractures of the petrous bone. Laryngoscope 1974;84:2141-54.

9. Liu Y, Han J, Zhou X, Gao K, Luan D, Xie F, et al. Surgical management of facial paralysis resulting 
from temporal bone fractures. Acta Otolaryngol 2014;134:656-60.

10. Ulug T, Arif Ulubil S. Management of facial paralysis in temporal bone fractures: a prospective study analyzing 11 operated fractures. Am J Otolaryngol 2005;26:230-8.

11. Yadav S, Panda NK, Verma R, Bakshi J, Modi M. Surgery for post-traumatic facial paralysis: are we overdoing it? Eur Arch Otorhinolaryngol 2018;275:2695-703.

12. Darrouzet V, Duclos JY, Liguoro D, Truilhe Y, De Bonfils C, Bebear JP. Management of facial paralysis resulting from temporal bone fractures: Our experience in 115 cases. Otolaryngol Head Neck Surg 2001;125:77-84. 